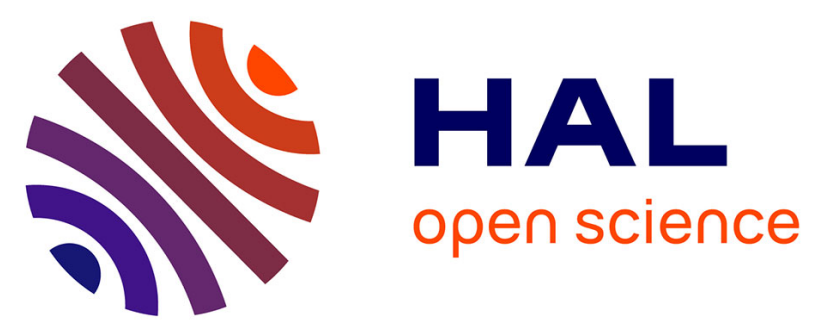

\title{
Experimental coupling and modelling of wet air oxidation and packed-bed biofilm reactor as an enhanced phenol removal technology
}

Marine Minière, Olivier Boutin, Audrey Soric

\section{- To cite this version:}

Marine Minière, Olivier Boutin, Audrey Soric. Experimental coupling and modelling of wet air oxidation and packed-bed biofilm reactor as an enhanced phenol removal technology. Environmental Science and Pollution Research, 2017, 24 (8), pp.7693-7704. 10.1007/s11356-017-8435-5 . hal-01629950

\section{HAL Id: hal-01629950 \\ https://hal-amu.archives-ouvertes.fr/hal-01629950}

Submitted on 6 Feb 2018

HAL is a multi-disciplinary open access archive for the deposit and dissemination of scientific research documents, whether they are published or not. The documents may come from teaching and research institutions in France or abroad, or from public or private research centers.
L'archive ouverte pluridisciplinaire $\mathbf{H A L}$, est destinée au dépôt et à la diffusion de documents scientifiques de niveau recherche, publiés ou non, émanant des établissements d'enseignement et de recherche français ou étrangers, des laboratoires publics ou privés. 


\title{
Experimental coupling and modelling of wet air oxidation and packed-bed biofilm reactor as an enhanced phenol removal technology
}

\author{
Marine Minière $^{1}$ • Olivier Boutin ${ }^{1}$ (D) Audrey Soric ${ }^{1}$
}

\begin{abstract}
Experimental coupling of wet air oxidation process and aerobic packed-bed biofilm reactor is presented. It has been tested on phenol as a model refractory compound. At $30 \mathrm{MPa}$ and $250{ }^{\circ} \mathrm{C}$, wet air oxidation batch experiments led to a phenol degradation of $97 \%$ and a total organic carbon removal of $84 \%$. This total organic carbon was mainly due to acetic acid. To study the interest of coupling processes, wet air oxidation effluent was treated in a biological treatment process. This step was made up of two packed-bed biofilm reactors in series: the first one acclimated to phenol and the second one to acetic acid. After biological treatment, phenol and total organic carbon removal was 99 and $97 \%$ respectively. Thanks to parameters from literature, previous studies (kinetic and thermodynamic) and experimental data from this work (hydrodynamic parameters and biomass characteristics), both treatment steps were modelled. This modelling allows the simulation of the coupling process. Experimental results were finally well reproduced by the continuous coupled process model: relative error on phenol removal efficiency was 1 and $5.5 \%$ for wet air oxidation process and packed-bed biofilm reactor respectively.
\end{abstract}

Olivier Boutin

olivier.boutin@univ-amu.fr

1 Aix Marseille Univ, CNRS, Centrale Marseille, M2P2, Marseille, France
Keywords Coupled process · Advanced oxidation process · Wet air oxidation $\cdot$ Biological treatment $\cdot$ Biofilm packed bed . Process modelling $\cdot$ Phenol

$$
\begin{aligned}
& \text { Nomenclature } \\
& \mathrm{A}_{\mathrm{F}} \quad \mathrm{m}^{2} \\
& \text { BOD } \quad \mathrm{g}_{\mathrm{BOD}} \mathrm{L}^{-1} \\
& \text { Biological oxygen demand } \\
& \mathrm{C}^{\mathrm{O} 2(\mathrm{~d})} \quad \mathrm{mol} \mathrm{L}^{-1} \\
& \mathrm{C}_{\mathrm{WAO}}{ }^{\mathrm{Hdq}} \mathrm{mol} \mathrm{L}^{-1} \\
& \text { Dissolved oxygen concentration in WAO } \\
& \text { Hydroquinone concentration in WAO } \\
& \mathrm{C}_{\mathrm{WAO}}{ }^{\mathrm{AcAc}} \mathrm{mol} \mathrm{L}^{-1} \\
& \begin{array}{cc}
\mathrm{C}_{\mathrm{WAO}} \mathrm{PhOH} & \text { Acetic acid concentration in WA } \\
& \mathrm{mol} \mathrm{L}^{-1} \\
\text { Phenol concentration in WAO }
\end{array} \\
& \mathrm{C}_{0} \mathrm{PhOH} \quad \mathrm{g} \mathrm{m}^{-3} \\
& \text { Phenol concentration at the packing/biofilm } \\
& \mathrm{C}_{\mathrm{B}} \mathrm{PhOH} \quad \mathrm{g} \mathrm{m}^{-3} \\
& \mathrm{C}_{\mathrm{F}} \mathrm{PhOH} \quad \mathrm{g} \mathrm{m}^{-3} \\
& \text { Phenol concentration in bulk liquid } \\
& \text { Phenol concentration at the biofilm/boundary } \\
& \mathrm{C}_{\text {in }} \mathrm{PhOH} \quad \mathrm{g} \mathrm{m}^{-3} \\
& \text { COD } \quad \mathrm{g}_{\mathrm{COD}} \mathrm{L}^{-1} \\
& \mathrm{D}_{\mathrm{F}}{ }^{\mathrm{PhOH}} \quad \mathrm{m}^{2} \mathrm{~s}^{-1} \\
& \mathrm{D}_{\mathrm{L}}{ }^{\mathrm{PhOH}} \quad \mathrm{m}^{2} \mathrm{~s}^{-1} \\
& \mathrm{~d}_{\mathrm{P}} \quad \mathrm{m}
\end{aligned}
$$




\begin{tabular}{|c|c|}
\hline & Packing characteristic size \\
\hline $\mathrm{j}_{\mathrm{F}} \mathrm{PhOH}$ & $\begin{array}{l}\mathrm{g}_{\text {phenol }} \mathrm{m}^{-2} \mathrm{~s}^{-1} \\
\text { Phenol flux }\end{array}$ \\
\hline $\mathrm{k}$ & $\mathrm{L} \mathrm{mol}^{-1} \mathrm{~s}^{-1}$ \\
\hline & Phenol oxidation rate constant \\
\hline $\mathrm{k}_{\mathrm{PhOH}}$ & $\begin{array}{l}\mathrm{m} \mathrm{s}^{-1} \\
\quad \text { Phenol mass transfer coefficient }\end{array}$ \\
\hline $\mathrm{K}_{\mathrm{i}}$ & $\begin{array}{l}\mathrm{g} \mathrm{m}^{-3} \\
\quad \text { Phenol inhibition constant }\end{array}$ \\
\hline $\mathrm{K}_{\mathrm{PhOH}}$ & $\begin{array}{l}\mathrm{g} \mathrm{m}^{-3} \\
\text { Phenol affinity constant }\end{array}$ \\
\hline $\mathrm{L}_{\mathrm{L}}$ & $\mathrm{m}$ \\
\hline $\mathrm{O}$ & $\begin{array}{l}\text { Boundary layer length } \\
\mathrm{m}^{3} \mathrm{~s}^{-1}\end{array}$ \\
\hline & Phenol flow rate \\
\hline $\mathrm{R}$ & $\begin{array}{l}\text { Ratio of phenol diffusion coefficient in biofilm } \\
\text { on phenol diffusion coefficient in water }\end{array}$ \\
\hline $\mathrm{r}$ & $\begin{array}{l}\mathrm{g}_{\text {COD }-\mathrm{X}} \mathrm{m}^{-3} \mathrm{~s}^{-1} \\
\text { Bacteria growth rate }\end{array}$ \\
\hline $\mathrm{r}^{\mathrm{PhOH}}$ & $\begin{array}{l}\mathrm{g}_{\text {phenol }} \mathrm{m}^{-3} \mathrm{~s}^{-1} \\
\text { Phenol consumption rate }\end{array}$ \\
\hline $\operatorname{Re}$ & Reynolds number \\
\hline $\mathrm{Sc}$ & Schmidt number \\
\hline Sh & Sherwood number \\
\hline $\mathrm{X}_{\mathrm{H}}$ & $\begin{array}{l}\mathrm{g}_{\mathrm{COD}-\mathrm{X}} \mathrm{m}^{-3} \\
\text { Biofilm density }\end{array}$ \\
\hline $\mathrm{X}_{\mathrm{V}}$ & $\begin{array}{l}\mathrm{kg}_{\mathrm{VS}} \mathrm{m}^{-3} \\
\quad \text { Biofilm density used in } \mathrm{R} \text { calculation }\end{array}$ \\
\hline $\mathrm{Y}_{\mathrm{X} / \mathrm{H}}$ & $\begin{array}{l}\mathrm{g}_{\text {COD-X }} \mathrm{g}_{\text {phenol }}{ }^{-1} \\
\text { Heterotrophic biomass yield }\end{array}$ \\
\hline $\mathrm{Z}$ & $\mathrm{m}$ \\
\hline & Distance from packing \\
\hline$\mu_{\max }$ & $\mathrm{s}^{-1}$ \\
\hline$v_{\text {water }}$ & $\begin{array}{l}\text { Specific growth rate } \\
\mathrm{m}^{2} \mathrm{~s}^{-1}\end{array}$ \\
\hline & Water kinematic viscosity \\
\hline
\end{tabular}

\section{Introduction}

Industrial wastewater treatment is a strong issue, as effluents could combine high organic waste concentration, refractory compounds at different concentrations and relatively low and intermittent flow rates. Chemical processes are known to be very efficient for the removal (oxidation) of many pollutants. They often involve chemical and/or energy consumption (Guieysse and Norvill 2014). On the contrary, biological processes are low-energy and maintenance consumers, but they are only efficient for biodegradable organic compounds. They cannot easily remove highly toxic pollutants or refractory compounds in normal operating conditions (Guieysse and Norvill 2014). Though a large range of processes are available, many pollutants, as for instance dyes, surfactants or pharmaceuticals, are still refractory to conventional treatments. Moreover, environmental protection involves more and more stringent regulations on pollutant discharge in aquatic environment.

One way to improve pollutant removal with limiting extra costs is to combine different processes in order to benefit from their advantages and to overcome their drawbacks. This could create complementary and synergistic effects. An interesting coupled process is the combination of chemical and biological processes. During the last 40 years, more than 200 studies have been published about chemical-biological-coupled processes. Four literature reviews (Guieysse and Norvill 2014; Scott and Ollis 1995; Mantzavinos and Psillaki 2004; Oller et al. 2011) relate the evolution of this field from 1976 to 2013. Moreover, integrated processes have also gained more and more attention (Di laconi 2012). According to the effluent, one of the two following sequences is more relevant:

- Biological-chemical treatments aim at degrading biodegradable compounds and mineralizing remaining compounds which are refractory to biodegradation. These coupled processes are suitable for effluents with high concentration of biodegradable compounds and low concentration of hardly biodegradable compounds, such as pulp and paper mill effluents (Assalin et al. 2009) or landfill leachates (Lei et al. 2007). They are also suitable if the biological treatment of an effluent leads to specific metabolites inhibiting bacterial activity: a chemical posttreatment allows their oxidation.

- Chemical-biological treatments are the oxidation of hardly biodegradable or inhibitory compounds into more biodegradable ones and then a degradation of those compounds through a biological treatment. These coupled processes allow saving energy or chemicals due to partial oxidation in comparison with total chemical mineralisation. They are suitable for effluents containing a high fraction of hardly biodegradable compounds, such as petrochemical effluents (Ishak and Malakahmad 2013), as well as effluents containing toxic or inhibitory elements to micro-organism compounds, such as textile effluents with toxic dyes or pesticide effluents (Libra and Sosath 2003; Pariente et al. 2013).

Chemical-biological processes are the most studied, as they can treat effluents with high toxicity. Among chemical and advanced oxidation processes, wet air oxidation (WAO) - an oxidation process in subcritical water at high temperature and pressure-is an efficient process with no chemical consumption (except oxygen or air). It can be optimised in terms of energy consumption (Lefevre et al. 2011). Verenich and Kallas (2002) showed that WAO as a pre-treatment could enhance biodegradability of pulp and paper mill effluents from 24 to $89 \%$. Moreover, this process can 
be economically viable for concentration of some relatively high wastes, due to its high efficiency and short residence time. However, an energy optimisation is needed in this case (Lefevre et al. 2011; Lefevre et al. 2012). Among biological processes, packed-bed biofilm reactors (PBBRs) are based on the biodegradation of pollutants by biomass attached on carriers (Warnoc et al. 2005; Ranade et al. 2011). They are very interesting since they need less space than suspended biomass reactors; they are easier to handle than fluidised bed bioreactors and also involve high sludge retention time leading to good efficiency. Zapata et al. (2010) successfully used a PBBR with a photo/Fenton pre-treatment for the decontamination of pesticide-containing wastewater, achieving $84 \%$ of mineralisation.

In many research studies, authors target model compounds. For instance, several studies on chemical-biological coupling use phenol, which is found in many industrial effluents (winery, olive mill, petrochemistry, coking, refinery, etc.) and which is dangerous for human health (Busca et al. 2008). Advanced oxidation process, coupled with biological process, is an interesting treatment for olive mill effluents containing high concentration of phenol (Mantzavinos and Kalogerakis 2005). For olive mill effluents, phenol concentrations can vary from $5.8 \mathrm{~g} \mathrm{~L}^{-1}$ (Rivas et al. 2001) to $29 \mathrm{~g} \mathrm{~L}^{-1}$ (Minh et al. 2008). Benitez et al. (1999) reached $84 \%$ of chemical oxygen demand (COD) removal from an olive mill wastewater by coupling ozonation with an aerobic biological treatment.

Although some studies give elements on the feasibility of coupling chemical-biological processes for the treatment of industrial effluents, they usually do not consider the whole and effective coupled process (Zapata et al. 2010; Wang et al. 2012). Most of them only analyse the chemically pretreated effluent in terms of biological oxygen demand (BOD) and COD without implementing the experimental study of the biological step with the real effluent coming from the oxidation step. Moreover, in a review on chemical oxidation as a pre-treatment for biodegradability enhancement, Mantzavinos and Psillaki (2004) emphasised the lack of models for predicting the removal efficiency of the coupled process. Guieysse and Norvill (2014) concluded that researches should focus on a better assessment of this coupled technology in terms of sensitivity to operational parameters in order to optimise the whole process. This lack in process modelling and process assessment leads to a lack in economic estimation of some coupled processes (Oller et al. 2011).

Thus, this study aims at experimentally demonstrating the interest of coupling wet air oxidation with a packed-bed biofilm reactor on phenol degradation as a compound found in many industrial effluents. Even if some results are reported in literature (Assalin et al. 2009 ; Benitez et al. 1999; Lei et al. 2007), the originality and the interest of this work is the effective experimental coupling of the two processes and the inherent removal efficiency. Then, each process was modelled and the whole process simulated in order to help the evaluation of this coupling approach.

\section{Materials and methods}

\section{Materials}

High-purity phenol (>99\%) and acetic acid of analytical grade were bought from Sigma-Aldrich and Carlo Erba Reagents respectively. Pink dye Rhodamine WT (20 wt\% rhodamine in water) for residence time distribution (RTD) experiments was bought from Acros Organics. Bioreactors were inoculated with samples of activated sludge from an urban wastewater treatment plant.

\section{Experimental setup}

The experimental coupling of wet air oxidation with packedbed biofilm reactors was carried out on a phenolic solution. First, oxidation of a phenolic solution was carried out in a batch WAO reactor. Then, the resulting effluent was biodegraded by the means of two PBBRs in series.

\section{Wet air oxidation step}

Figure 1 shows the wet air oxidation batch reactor (Top Industrie, France). It was composed of a $152.8-\mathrm{mL}$ stainless steel reactor equipped with a stirrer (Rushton propeller, maximum speed $2000 \mathrm{rpm}$ ). It was connected to a volumetric pump allowing injection of either phenolic solution, oxygen or nitrogen at a given volume or pressure. Maximum temperature and pressure were set at $350^{\circ} \mathrm{C}$ and $30 \mathrm{MPa}$ respectively. Temperature was regulated, thanks to a cooling jacket and an electric heating collar. Liquid samples were collected via a valve located at the bottom of the reactor.

A phenolic solution of $9.3 \mathrm{~g} \mathrm{~L}^{-1}$ was prepared. This value is in the range of concentration in olive mill effluents and allowed decreasing the number of batch experiments. The operating conditions were chosen from previous experiments realised by our group to achieve a high removal rate of phenol with low concentration of residual phenol and high concentration of accumulated acetic acid (Lefevre et al. 2011). Temperature was set at $250^{\circ} \mathrm{C}$ and pressure at $30 \mathrm{MPa}$, with a residence time of $15 \mathrm{~min}$ and an air factor (ratio between the oxygen really introduced to the oxygen needed at stoichiometry) of 1.7.

First, the reactor was heated at $60{ }^{\circ} \mathrm{C}$ and pressurised at 2.6 $\mathrm{MPa}$ with nitrogen, the initial pressure being estimated from thermodynamic calculations using the Soave-RedlichKwong equation of state (Lefevre et al. 2011). Sixty millilitres of phenolic solution was injected, and the reactor was isolated and stirred. When the set temperature was reached, air was injected at the set pressure and the reaction began $(t=0)$. 
Finally, after $15 \mathrm{~min}$, the reactor was purged and the preoxidised solution was collected. This solution was kept at $4{ }^{\circ} \mathrm{C}$, waiting for further biological treatment.

This procedure was done 15 times in order to recover $900 \mathrm{~mL}$ of pre-oxidised solution. This volume is necessary for biological operation conditions.

\section{Packed-bed biofilm reactors}

To enhance phenol biodegradation, a hardly biodegradable compound and a biological inhibitor, an acclimation phase is required. Two PBBRs were implemented in series: one acclimated to phenol and the other one fed with acetic acid. Then, the following series sequence was chosen: WAO effluent passed through the phenol-acclimated PBBR followed by acetic acid-fed PBBR. This allowed reducing phenol concentration and its inhibitory effect on the non-acclimated biofilm of the second reactor.

All experiments were conducted at ambient temperature $\left(20{ }^{\circ} \mathrm{C}\right)$ in aerobic conditions. The bioreactors were made of a plastic cylinder of $4.6 \mathrm{~cm}$ of intern diameter schemed on Fig. 2. They were filled with Kaldnes K1® plastic packing till $25 \mathrm{~cm}$ height, supported by a stainless steel grid. Packing was $9.1 \mathrm{~mm}$ in diameter, $7.2 \mathrm{~mm}$ high with a porosity of $93 \%$ and a total specific area of $800 \mathrm{~m}^{2} \mathrm{~m}^{-3}$ and protected surface area of $500 \mathrm{~m}^{2} \mathrm{~m}^{-3}$. Total volume of the bed is $450 \mathrm{~cm}^{3}$. Feeding solution was brought thanks to a Masterflex pump, and the reactor was operated downflow with unsaturated conditions. Pebbles were placed at the top of the packing to allow good distribution of the feeding solution and to retain packing during backwashing. Aeration was done through air bubbling of the feeding tank and by natural draft.

Bacteria inoculum comes from an urban wastewater treatment plant located in Aix en Provence (France). The average concentration of suspended solids in the initial sample is $6.2 \pm 1.9 \mathrm{~g} \mathrm{~L}^{-1}$. In order to avoid any plugging problems, the sludge was diluted to reach a concentration of $350 \mathrm{mg} \mathrm{L}^{-1}$. The inoculation phase consisted in a 2-day batch recirculation of the inoculum mixed with sucrose and nutrients. After the inoculation, the acclimation was carried out by feeding the PBBRs with increasing concentrations of acclimation substrate: phenol PBBR was acclimated for 43 days to a maximal phenol concentration of $800 \mathrm{mg} \mathrm{L}^{-1}$, whereas acetic acid PBBR was fed for 23 days with a maximal acetic acid concentration of $944 \mathrm{mg} \mathrm{L}^{-1}$. These durations allowed sufficient biomass growth. The feeding solution was recirculated continuously in the biofilter at a flow of $0.3 \mathrm{~L} \mathrm{~h}^{-1}$. It was renewed every day. $\mathrm{NH}_{4} \mathrm{Cl}$ and $\mathrm{KH}_{2} \mathrm{PO}_{4}$ were added as nutrients to the substrate solution at a C/N/P mass ratio of 100:5:1. For the treatment of the effluent coming from the WAO process, the PBBRs were feeding at a flow rate of $0.3 \mathrm{~L} \mathrm{~h}^{-1}$.

\section{Methods and analysis}

\section{Effluent analysis}

Phenol, hydroquinone and acetic acid concentrations in the liquid samples are determined with gas chromatography. A Varian 3800 GC equipped with a CP-Sil 5 CB column and a flame ionisation detector was used with the following analytical method: injection temperature of $250{ }^{\circ} \mathrm{C}$, column pressure of $0.079 \mathrm{MPa}$, detector temperature of $320^{\circ} \mathrm{C}$, helium flow (vector gas) of $17 \mathrm{~mL} \mathrm{~min}^{-1}$ and inlet pressure of $0.275 \mathrm{MPa}$ for hydrogen, 0.41 MPa for air and $0.55 \mathrm{MPa}$ for helium. The temperature program started with a rise from 95 to $150{ }^{\circ} \mathrm{C}$ for $5.5 \mathrm{~min}$, followed by $4 \mathrm{~min}$ at $150{ }^{\circ} \mathrm{C}$ and a final rise from 150 to $300{ }^{\circ} \mathrm{C}$ during $7.5 \mathrm{~min}$. Using results from total organic carbon measurements and mass balances, the compounds detected through this GC analysis represent between 90 and $95 \%$ of the mass of carbon in each sample, in the conditions tested. An example of chromatogram evolutions is given in Sect. 2 of supplementary materials section.

\section{Characterisation of the phenol-acclimated PBBR}

Experimental data on the phenol-acclimated PBBR was necessary for modelling: hydrodynamic behaviour, biomass analysis and performances of the bioreactor.

Hydrodynamic characterisation Hydrodynamic behaviour of the PBBR was analysed by residence time distribution measurements using Rhodamine as a tracer. This tracer was recovered at the exit between 96 and 100\% and hence not degraded by bacteria, confirming it is a hardly biodegradable compound. A tracer solution made of both substrate (phenol at acclimation concentration) and Rhodamine WT (at $0.06 \mathrm{mg} \mathrm{L}^{-1}$ ) was injected under a step injection form. Finally, the effluent was regularly sampled for $3 \mathrm{~h}$ and analysed. A calibration curve of the absorbance at $555 \mathrm{~nm}$ of a Rhodamine WT solution, as a function of its concentration, was obtained. Presence of phenol had no influence on the absorbance of the Rhodamine solution at $555 \mathrm{~nm}$.

Biomass analysis A local mass balance in biofilm is also necessary to implement a PBBR model. This mass balance requires the knowledge of some biomass characteristics. Biomass density in biofilm is the quantity of active biomass per volume of biofilm. Biofilm volume was calculated assuming a biofilm density of $1.0 \mathrm{~g} \mathrm{~L}^{-1}$ since it is mainly constituted of water. Active biomass is the fraction of biomass which really degrades the substrate; the other fraction is the dead biomass which degraded over time in the deep layer of the biofilm. It was obtained from the volatile solid weight converted in chemical oxygen demand by considering the following factor value $1.42 \mathrm{~g}_{\mathrm{DCO}-\mathrm{X}} \mathrm{g}_{\mathrm{VS}}{ }^{-1}$ (IWA Publishing 2006). 
Fig. 1 Wet air oxidation batch reactor

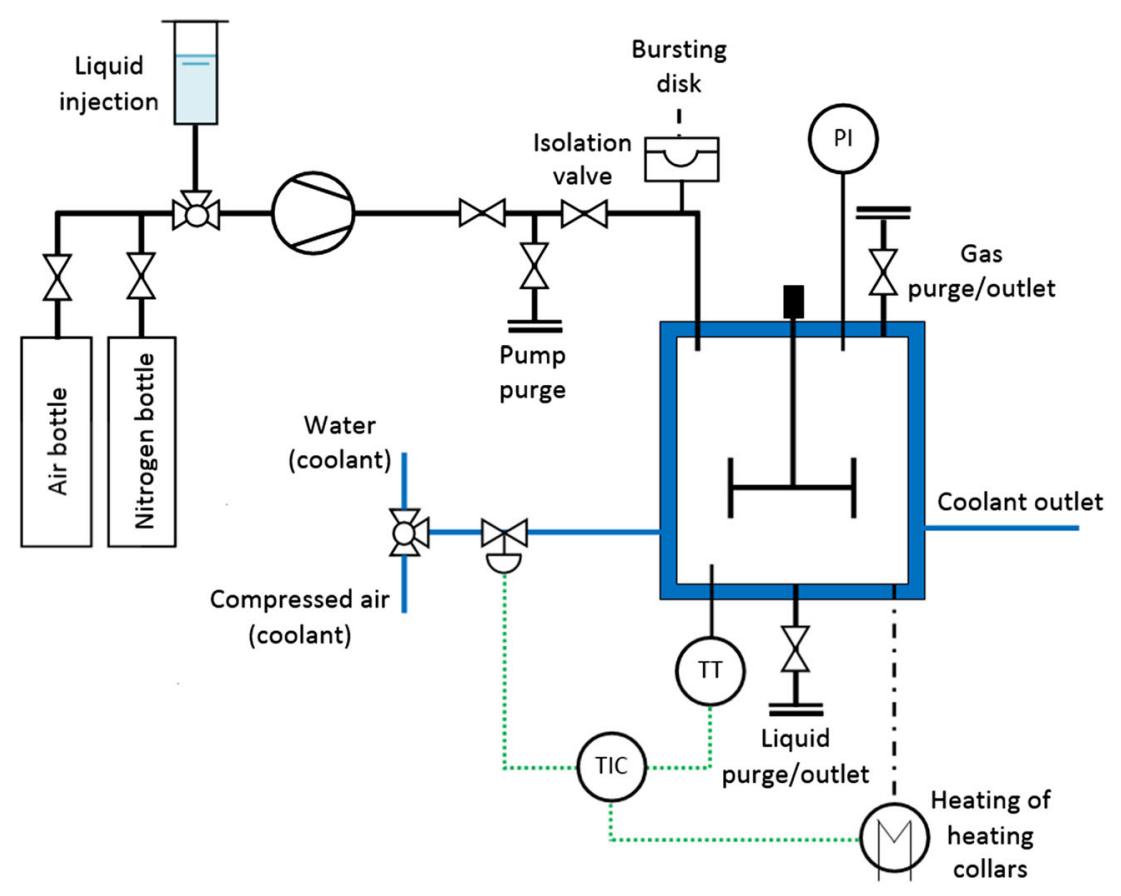

The weights of the wet biofilm and solids were determined as follows: few packings were sampled, weighted and sonicated for $20 \mathrm{~min}$ in $30 \mathrm{~mL}$ of deionised water for biomass detachment. Centrifugation at $13500 \mathrm{rpm}$ for $15 \mathrm{~min}$ allowed removing supernatant water. Then, the solid phase was recovered, dried at $105{ }^{\circ} \mathrm{C}$ for $24 \mathrm{~h}$ and weighted to determine the total solid fraction. Finally, the sample was heated at $550{ }^{\circ} \mathrm{C}$ for $5 \mathrm{~h}$ (until mass stabilised) and weighted to calculate the total volatile solid fraction.

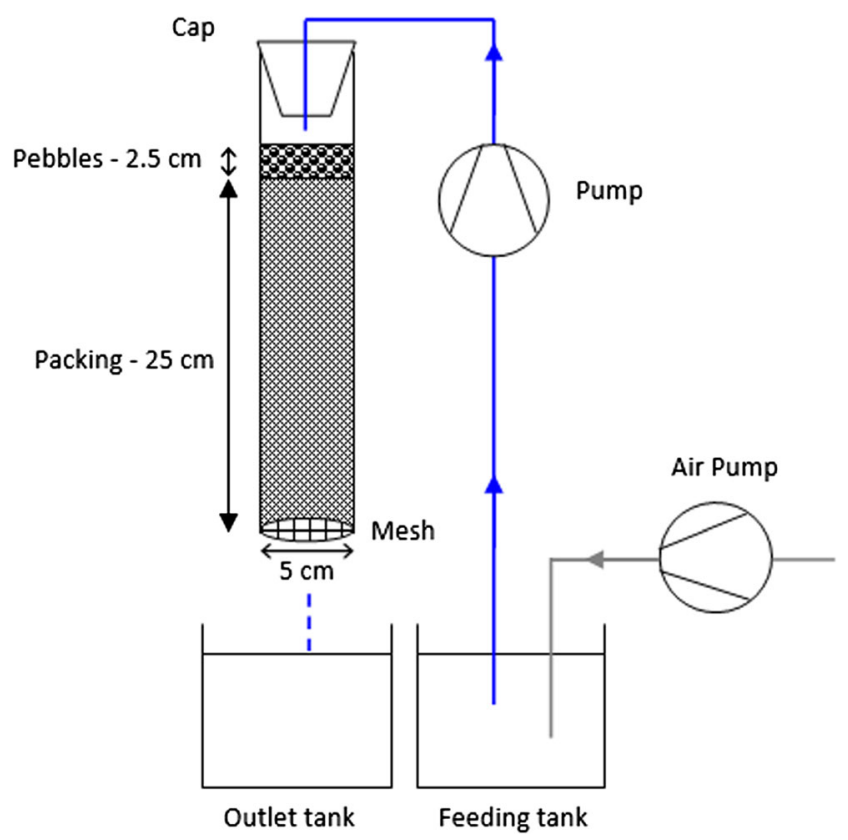

Fig. 2 Packed-bed biofilm reactor

\section{Coupled-process modelling}

\section{Wet air oxidation modelling}

Wet air oxidation was simulated using the software ProsimPlus ${ }^{\circledR}$ (Prosim, France). Predictive Soave-RedlichKwong thermodynamic model was chosen (Lefevre et al. 2011).

A model with two intermediate compounds (acetic acid and hydroquinone which are the two main degradation compounds identified through GC analysis) and three reactions was considered, with their associated reaction rates $r_{i}$ :

$$
\begin{aligned}
& \mathrm{C}_{6} \mathrm{H}_{5} \mathrm{OH}+\xi \mathrm{O}_{2} \rightarrow \mathrm{C}_{6} \mathrm{H}_{6} \mathrm{O}_{2} r_{1}=k_{1} \cdot C_{W A O}^{\mathrm{PhOH}} \cdot C^{O_{2}(d)} \\
& \mathrm{C}_{6} \mathrm{H}_{6} \mathrm{O}_{2}+6 \mathrm{O}_{2} \rightarrow ¥ \mathrm{C}_{2} \mathrm{H}_{4} \mathrm{O}_{2}+5.5 \mathrm{CO}_{2}+2.5 \mathrm{H}_{2} \mathrm{O} r_{2} \\
& \quad=k_{2} \cdot C_{W A O}^{H d q} \cdot C^{O_{2}(d)} \\
& \mathrm{C}_{2} \mathrm{H}_{4} \mathrm{O}_{2}+2 \mathrm{O}_{2} \rightarrow 2 \mathrm{CO}_{2}+2 \mathrm{H}_{2} \mathrm{O} r_{3}=k_{3} \cdot C_{W A O}^{\mathrm{AcAc}} \cdot C^{O_{2}(d)}
\end{aligned}
$$

The kinetic parameter was taken from a previous study (Lefevre et al. 2011).

A simulation was developed considering the continuous cocurrent bubble column, as in many industrial plants (Debellefontaine et al. 1999). The experimental conditions previously given are the same, but here a bubble column is simulated, different from the batch reactor used to obtain degradation rates and molecular composition. Hydrodynamics of this kind of reactors can be quite complex since it depends on many parameters as axial dispersion, gas hold-up and gas-liquid interfacial area (Kantarci et al. 2005). However, a hydrodynamic model with five isothermal continuously stirred tank reactors 
(CSTRs) in series can be assumed (Lefevre et al. 2011). Oxygen and nitrogen input flow rates were automatically calculated using an air factor of 1.7. Pressure is set to $25 \mathrm{MPa}$ and temperature to $250{ }^{\circ} \mathrm{C}$. Vapour and liquid outputs were finally cooled at $20^{\circ} \mathrm{C}$ and relaxed at atmospheric pressure.

\section{Phenol-acclimated PBBR modelling}

The phenol-acclimated PBBR was modelled with three compartments as shown in Fig. 3. Two components were used: biomass as particulate compound and phenol as dissolved compound. It was assumed that phenol was the limiting substrate. Steady state was also assumed, which implied that biomass concentration and biofilm thickness were constant over time. Thanks to RTD experiments, it has been proven that the bulk liquid was completely mixed (see "Phenol-acclimated PBBR" section), so that the concentrations were homogeneous all along this compartment. This result has been yet obtained for a more general case of packed columns under trickle-flow conditions, also through RTD experiments (Van Swaaij et al. 1969). A boundary layer involved phenol mass transfer resistance between bulk liquid and biofilm. Diffusion and reaction processes both occurred inside the biofilm. Phenol consumption was only considered inside the biofilm: degradation occurring in the bulk liquid due to small quantities of suspended biomass was neglected.

\section{Equations}

The following phenol mass balances result from the previous hypothesis: bulk liquid Eq. (4), boundary layer Eq. (5) and biofilm Eq. (6). These equations respect two conditions: flux continuity at the boundary layer/biofilm interface Eq. (7) and no flux at the biofilm/packing interface Eq. (8).

$$
\begin{aligned}
& Q \cdot\left(C_{\mathrm{in}}^{\mathrm{PhOH}}-C_{B}^{\mathrm{PhOH}}\right)+j_{F}^{\mathrm{PhOH}} \cdot A_{F}=0 \\
& -D_{L}^{\mathrm{PhOH}} \frac{d^{2} C^{\mathrm{PhOH}}}{d z^{2}}=0 \\
& -D_{F}^{\mathrm{PhOH}} \frac{d^{2} C^{\mathrm{PhOH}}}{d z^{2}}+r^{\mathrm{PhOH}}=0
\end{aligned}
$$

$$
\begin{aligned}
& j_{F}^{\mathrm{PhOH}}=-\left.D_{F}^{\mathrm{PhOH}} \frac{d C^{\mathrm{PhOH}}}{d z}\right|_{z=L_{F}}=-k_{\mathrm{PhOH}}\left(C_{F}^{\mathrm{PhOH}}-C_{B}^{\mathrm{PhOH}}\right) \\
& -\left.D_{F}^{\mathrm{PhOH}} \frac{d C^{\mathrm{PhOH}}}{d z}\right|_{z=0}=0
\end{aligned}
$$

As phenol is an inhibitory compound, Haldane kinetics was used (see Eq. (9) and Eq. (10)).

$$
\begin{aligned}
& r^{\mathrm{PhOH}}=-\frac{1}{Y_{X / H}} \cdot r \\
& r=\mu_{\max } X_{H} \cdot \frac{C^{\mathrm{PhOH}}}{C^{\mathrm{PhOH}}+K_{\mathrm{PhOH}}+\frac{C^{\mathrm{PhOH} 2}}{K_{I}}}
\end{aligned}
$$

The problem was solved as a second-order non-linear differential equation with given initial conditions:

$C_{0}^{\mathrm{PhOH}}$ and $\left.\frac{d C^{\mathrm{PhOH}}}{d z}\right|_{z=0}=0$

The resolution consisted in finding the initial value $C_{0}^{\mathrm{PhOH}}$ respecting the condition presented in Eq. (4). The resolution of second-order non-linear differential equation was done using the 4th order Adams-Bashforth method initialised with the Runge-Kutta 4 method.

\section{Parameters}

Phenol diffusion coefficients in biofilm were calculated using Fan correlation (Fan et al. 1990); see Eq. (12). Even if biofilm is mainly constituted of water (intra- and extra-cellular water), the presence of bacteria (solid material) limits diffusion compared to pure water.

$R=\frac{D_{F}^{\mathrm{PhOH}}}{D_{L}^{\mathrm{PhOH}}}=1-\frac{0.43 * X_{V}^{0.92}}{11.19+0.27 * X_{V}^{0.99}}$

The phenol mass transfer coefficient was calculated using correlation (13) (Logan 2012). This correlation is valid for Reynolds between $10^{-3}$ and 5.8 (in this study, $\mathrm{Re}=0.35$ ). Boundary layer thickness was calculated as $L_{L}=D_{L}^{\mathrm{PhOH}} / k_{\mathrm{PhOH}}$.
Fig. 3 Biofilm model schematic representation - phenol concentration evolution along the three compartments: biofilm, boundary layer and bulk liquid

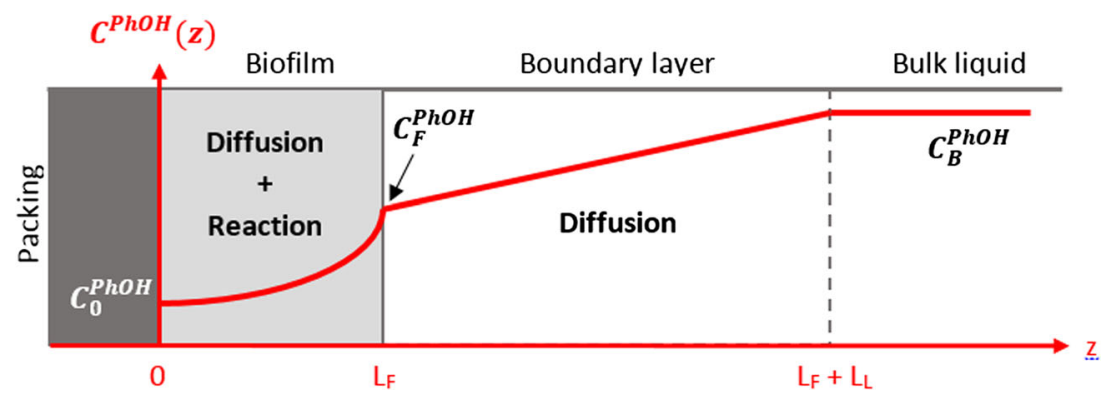


Table 1 Physical and kinetic parameters used in the PBBR model

\begin{tabular}{lllll}
\hline Parameters & & Unit & Value & Reference \\
\hline Physical parameters & $\mathrm{D}_{\mathrm{L}}{ }^{\mathrm{PhOH}}$ & $\mathrm{m}^{2} \mathrm{~s}^{-1}$ & $8.8 .10^{-10}$ & Toxicity datasheet (INERIS) \\
& $\mathrm{k}_{\mathrm{PhOH}}$ & $\mathrm{m} \mathrm{s}^{-1}$ & $1.35 .10^{-6}$ & Logan 2012 \\
Kinetic parameters & $\mu_{\max }$ & $\mathrm{h}^{-1}$ & 0.308 & Saravan et al. 2008 \\
& $\mathrm{K}_{\mathrm{PhOH}}$ & $\mathrm{mg} \mathrm{L}^{-1}$ & 44.9 & \\
& $\mathrm{~K}_{\mathrm{i}}$ & $\mathrm{mg} \mathrm{L}^{-1}$ & 525 & Nuhoglu and Yalcin 2005 \\
& $\mathrm{Y}_{\mathrm{X} / \mathrm{H}}$ & $\mathrm{gSS}_{\text {phenol }}{ }^{-1}$ & 0.6 & Pawlowsky and Howel 1973 \\
\hline
\end{tabular}

$\mathrm{Sh}=\frac{k_{\mathrm{PhOH}} d_{p}}{\nu_{\text {water }}}=2+1.58 * \mathrm{Re}^{0.4} * \mathrm{Sc}^{1 / 3}$

Kinetic parameters (Table 1) were taken from Saravanan's study since it has similar characteristics with the present study (Saravan et al. 2008). The yield factor $Y_{X / H}$ was taken from other studies reported in the literature (Nuhoglu and Yalcin 2005; Hsien and Lin 2005; Pawlowsky and Howell 1973).

\section{Results and discussion}

\section{Experimental results}

\section{Wet air oxidation}

Wet air oxidation of the initial phenolic solution led to a high phenol removal rate of $97 \%$. Analysis revealed a high concentration of acetic acid $\left(2.4 \mathrm{~g} \mathrm{~L}^{-1}\right)$. According to the GC chromatograms, only those two organic compounds were detected, so that $84 \%$ of total organic carbon (TOC) removal was calculated. Eighty-three percent of remaining TOC was due to acetic acid.

\section{PBBRs in series}

As TOC concentration of the pre-oxidised effluent is quite high, it was twice diluted to avoid stressing bacteria. This obviously would not be done in an industrial process, but the phenol initial concentration has been chosen high in order to decrease the number of WAO experiments at the laboratory scale. Phenol-acclimated PBBR has led to 60,51 and $53 \%$ of phenol, acetic acid and TOC removal respectively. Phenol removal efficiency has indicated that biomass was successfully acclimated to phenol. Acetic acid removal efficiency has also shown that, even if phenol-degrading biomass was selected during the acclimation step, acetic acid was easily biodegradable by this bacterial consortium. Moreover, acetate is a metabolic intermediate of many carbon sources, such as glucose and potentially phenol, so that the net removal efficiency might represent both production (due to phenol degradation) and consumption of acetic acid (Bajaj et al. 2008). After 34 days of phenol acclimation, removal efficiency of a synthetic phenolic solution of $800 \mathrm{mg} \mathrm{L}^{-1}$ was $35 \%$. This rate was relatively low and much lower than in the coupling experiment $(60 \%)$. This can be explained by two main reasons: phenol concentration was higher $\left(800 \mathrm{mg} \mathrm{L}^{-1}\right.$ against $133 \mathrm{mg} \mathrm{L}^{-1}$ ) so the inhibitory nature of phenol had more impact, and high fraction of dead volume (according to RTD results) decreased the performance of the whole PBBR. Nevertheless, this result was consistent with those found in other studies (Zapata et al. 2010; Wang et al. 2012). Two results from literature are lower than the removal efficiency achieved in this study (Nuhoglu and Yalcin 2005; Marrot et al. 2006) (Table 2). In the Nuhoglu and Yalcin (2005) study, the lower biomass concentration probably explained this
Table 2 Comparison between this study and literature

\begin{tabular}{|c|c|c|c|c|}
\hline Characteristic & Unit & Marrot et al. 2006 & $\begin{array}{l}\text { Nuhoglu and Yalcin } \\
2005\end{array}$ & $\begin{array}{l}\text { This } \\
\text { study }\end{array}$ \\
\hline Acclimation process & l & $\begin{array}{r}\text { Suspended } \\
\text { biomass }\end{array}$ & Suspended biomass & Biofilm \\
\hline Acclimation phenol concentration & $\mathrm{g} \mathrm{L}^{-1}$ & 3.0 & 1.45 & 0.8 \\
\hline Acclimation time & day & 120 & 25 & 34 \\
\hline Tested phenol concentration & $\mathrm{g} \mathrm{L}^{-1}$ & 0.7 & 0.68 & 0.8 \\
\hline Residence time & $\min$ & 15 & 30 & 16 \\
\hline $\begin{array}{l}\text { Biomass concentration per void } \\
\text { volume }\end{array}$ & $\mathrm{g} \mathrm{L}^{-1}$ & $9-10$ & $1.8-2.0$ & 14.3 \\
\hline Phenol removal efficiency & $\%$ & 30 & 25 & 35 \\
\hline
\end{tabular}


Table 3 Phenol, acetic acid and TOC concentrations at different stages of the coupled process

\begin{tabular}{lrlr}
\hline Concentration $\left(\mathrm{mg} \mathrm{L}^{-1}\right)$ & Phenol & Acetic acid & TOC \\
\hline Initial influent & 9320 & $/$ & 7132 \\
Pre-oxidised effluent & 252 & 2366 & 1138 \\
Diluted effluent & 133 & 1252 & 602 \\
Biologically treated effluent-1st PBBR & 53 & 608 & 284 \\
Biologically treated effluent—2nd PBBR & 49 & 141 & 94 \\
Final removal efficiencies & $99 \%$ & $/$ & $97 \%$ \\
\hline
\end{tabular}

difference. On the contrary, in the Marrot et al. (2006) study, operating conditions were very close to this study but the acclimation time and concentration were higher, which should involve higher rates. Indeed, this lower performance might be explained by the acclimation process: acclimation of suspended biomass seems less efficient than acclimation of attached biomass in a biofilm. This phenomenon may be a consequence of the physical structure of biofilm: development of slow-growing organisms (able of degrading phenol in this case) is facilitated thanks to small biological niches where they are protected and cannot be washed out like in homogenous systems (IWA Publishing 2006). The Pishga (2011) study on anaerobic phenol biodegradation confirmed this observation by comparing the performances of free and immobilised cells both acclimated to $1000 \mathrm{mg} \mathrm{L}^{-1}$ of phenol. It was shown that, at high concentration of phenol (over $500 \mathrm{mg} \mathrm{L}^{-1}$ ), phenol removal efficiencies were significantly higher in immobilised cell experiments.

Acetic acid-fed PBBR led to 7, 77 and $67 \%$ of phenol, acetic acid and TOC removal respectively. Phenol removal efficiency in the second PBBR was very low: bacteria consortium was clearly not adapted to phenol degradation which confirms that specific biomass or specific acclimation is necessary to ensure phenol degradation. The acetic acid removal efficiency is consistent with pilot-scale experiments conducted by Zeng et al. (2013) who achieved 69\% of TOC removal in an aerobic PBBR also packed with Kaldnes K1 and fed with a synthetic effluent made of easily biodegradable organic compounds.

Regarding the whole biological treatment, the removal efficiencies of phenol, acetic acid and TOC were finally 63,89 and $84 \%$ respectively. It was also demonstrated that coupling two PBBRs with different bacteria consortia leads to better performances than using only one of them.

\section{Overall experimental results}

The results regarding the process coupling are summarised in Table 3. Phenol degradation was mainly due to pre-oxidising but was also slightly improved thanks to the biological treatment (from 97 to 99\%). Besides, biological treatment clearly improved TOC removal (from 84 to $97 \%$ ) since organic carbon was mainly due to accumulated acetic acid which is refractory to chemical oxidation but easily biodegradable. Finally, these results clearly demonstrated the feasibility and the interest of coupling wet air oxidation with PBBR as a treatment of a refractory compound.

Biomass analysis indicates that reactional volume changes with time, probably generated by biomass clogging some parts of the reactor (more details in supplementary material, Sect. 1).

\section{Modelling results}

The general scheme of the simulation of the whole coupled process is proposed in Fig. 4.

\section{Wet air oxidation process}

Wet air oxidation simulation on ProsimPlus ${ }^{\circledR}$ was conducted considering a phenol solution input flow rate of $0.3 \mathrm{~L} \mathrm{~h}^{-1}$ (see Fig. 5). CSTR volumes (and so on the residence time) were adjusted to obtain a similar phenol removal efficiency than in

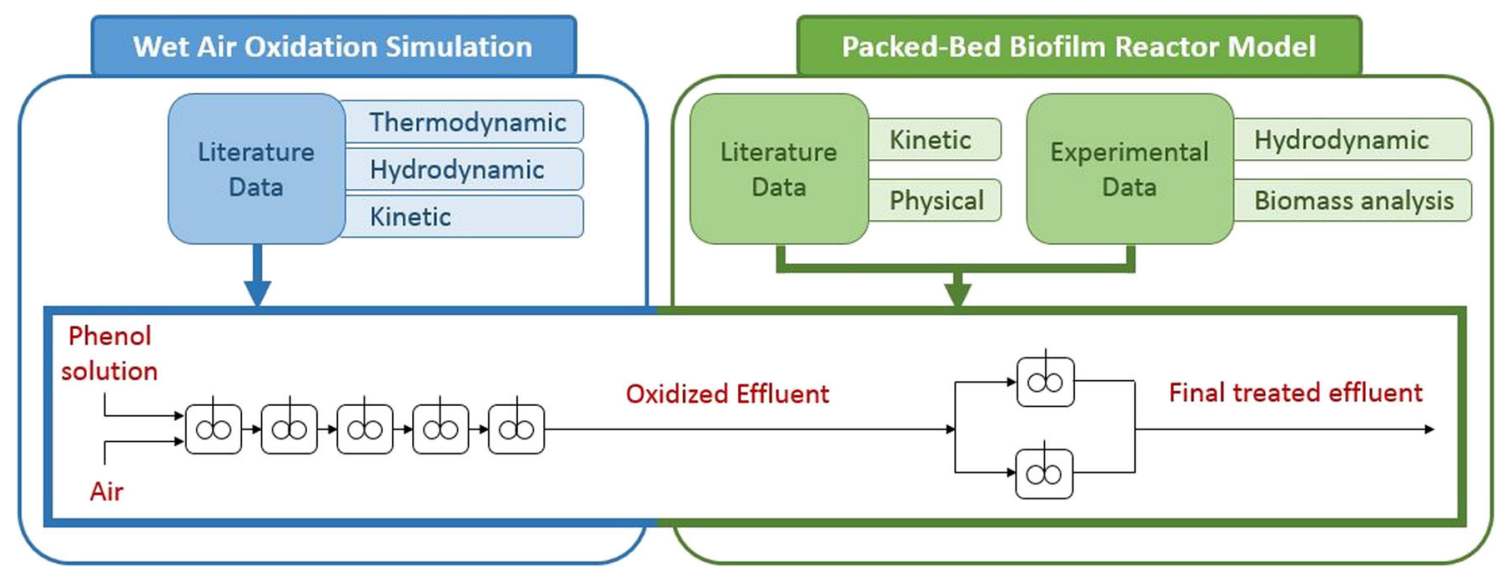

Fig. 4 Schematic diagram representing the coupled process modelling method 


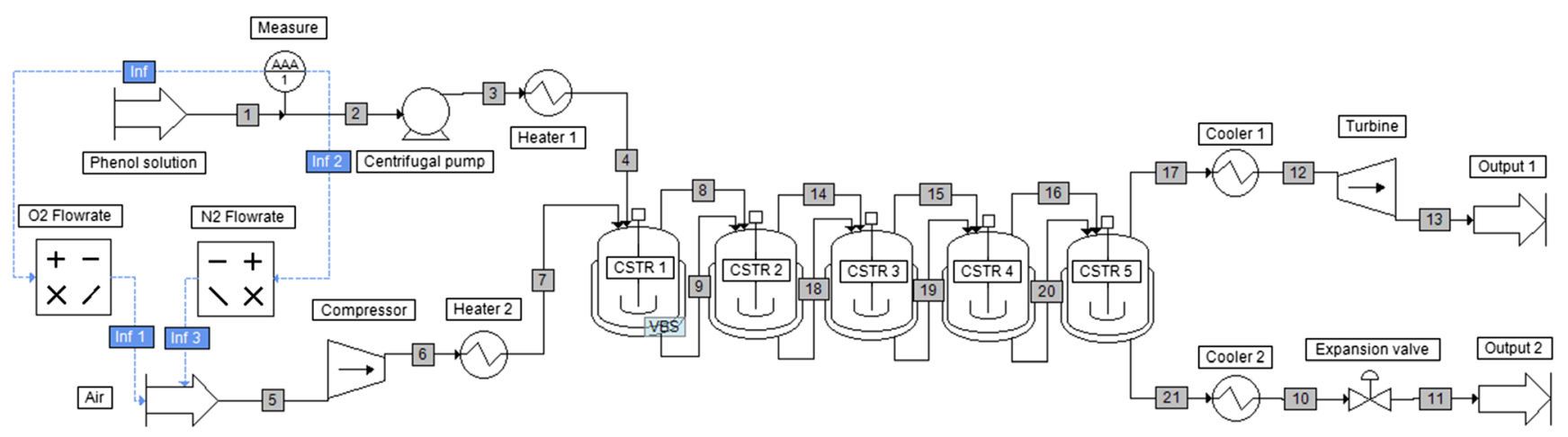

Fig. 5 Wet air oxidation simulation on ProsimPlus ${ }^{\circledR}$ software

the batch WAO experiment: with five CSTRs of $15 \mathrm{~mL}$ each - that is, a total residence time of $6.6 \mathrm{~min}-96 \%$ of removal was obtained. These five CSTRs simulate a real industrial bubble column usually used for wet air oxidation.

\section{Phenol-acclimated PBBR}

Hydrodynamic behaviour Cumulative residence time distribution was well represented by two parallel CSTRs (volume $\mathrm{V}_{1}$ and $\mathrm{V}_{2}$ ) with a different flow in each branch (flow ratio $\alpha$ ) as shown in Fig. 6 and related (see more details in supplementary material, Sect. 3). RTDs were determined after 34 and 43 days of phenol acclimation.

According to RTD results, reactional volume - and so on the residence time - was very low on day 34 . For this reason, the PBBR was backwashed on day 35 with water and air bubbles for $30 \mathrm{~min}$. One week later, another RTD experiment was done (day 43). It showed that backwashing was efficient since the reactional volume was more than doubled.

Comparison between model and experiment Modelled and experimental removal efficiencies were very close: 32 and $35 \%$ respectively for the experiment on day 34 (relative error of $8 \%$ ) and 56 and $60 \%$ respectively for the coupling experiment on day 43 (relative error of $7 \%$ ).
The phenol concentration profiles (as a function of biofilm and boundary layer thicknesses) are shown in Fig. 7. It appears that the low phenol mass transfer coefficient involved a very thick boundary layer of $630 \mu \mathrm{m}$, which is higher than the biofilm itself $(425 \mu \mathrm{m})$. Besides, most of phenol degradation occurred in the first half of the biofilm. This shows that a high fraction of biomass was not really active in the biofilm. Thus, it shows that a regular backwashing of the reactor is necessary in order to increase the reaction volume instead of growing a too thick and partly inactive biofilm. However, frequency of backwashing must also be low enough to allow a good development of slow-growing bacteria and to increase sludge retention time. Frequency and duration of backwashing are parameters that must be optimised.

Influence of operating parameters Since the model shows good accordance with experimental results, it is interesting to assess the influence of some operating parameters on the predicted phenol removal efficiency. Data from the coupling experiment (day 43) was used to obtain the results shown in Table 4. Phenol flow rate is one of the most important parameters to optimise phenol degradation. Indeed, if flow rate is twice decreased (i.e. residence time doubled), removal efficiency is improved from 56 to $65 \%$. On the contrary, with
Fig. 6 Experimental and modelled cumulative residence time distribution in function of time (day 34) with schematic model representation (deviation is less than $15 \%$ )

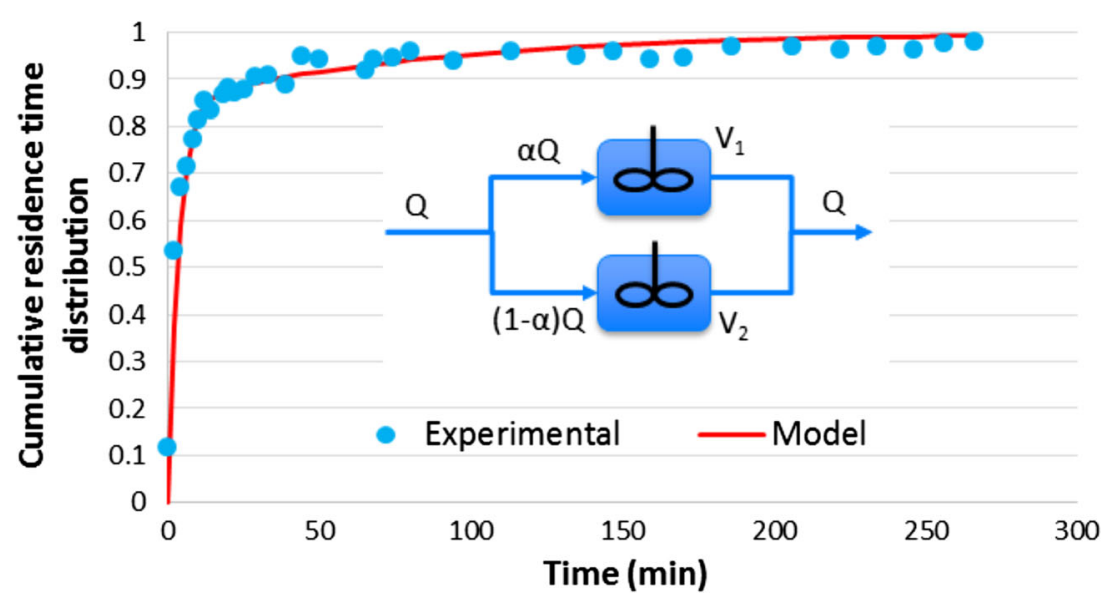


Fig. 7 Modelled phenol concentration profiles in CSTR 1 and CSTR 2 in the first experiment (day 34)
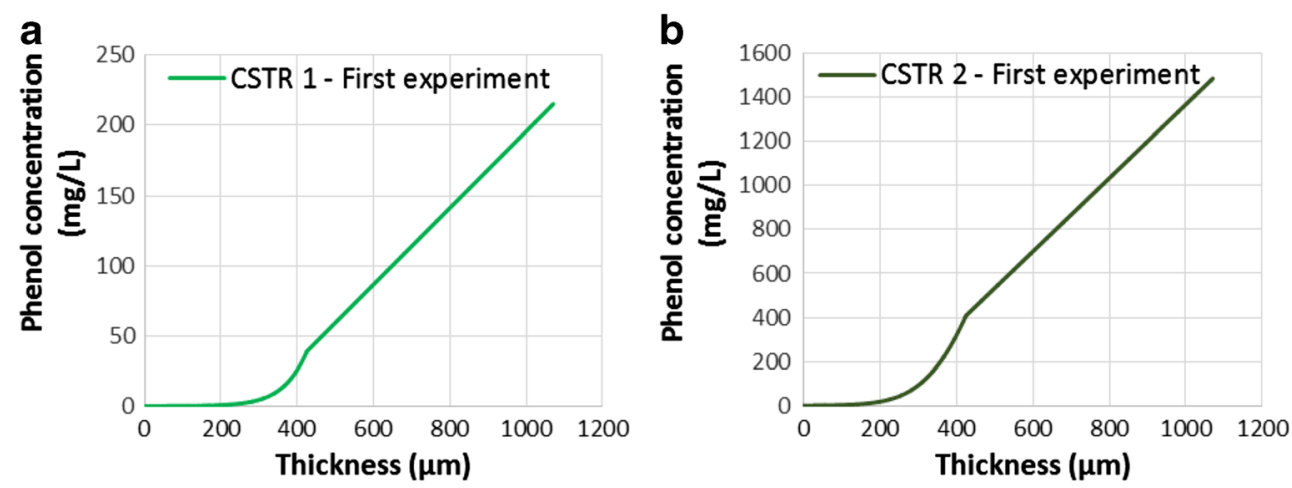

the tested conditions, phenol concentration and biomass density do not influence phenol removal efficiencies.

To conclude, this model, established from both experimental and literature data, fits well the experimental results and could be used in a global simulation integrating both WAO and PBBR.

\section{Overall modelling results}

Input flow rates in WAO simulation and in the PBBR model were $0.3 \mathrm{~L} \mathrm{~h}^{-1}$, so that continuity was ensured. Besides, phenol WAO output concentration was used as input of the PBBR model. Results of this continuous coupled process modelling are very similar to experimental results (see Table 5): the relative difference between modelled and experimental phenol removal efficiencies was 1,5 and $1 \%$ for the WAO, phenol-acclimated PBBR and global coupled process respectively.

As phenol flow rate (residence time) was an important parameter in PBBR modelling, its influence on the phenol removal efficiency of the whole coupled process has been assessed. If phenol flow rate is increased by $50 \%$ (4.4 min of residence time), removal efficiencies in the WAO, PBBR and global processes are $94.3,46.7$ and $97.0 \%$ respectively. In the other case where phenol flow rate is increased by $50 \%$ ( 9.9 min of residence time), removal efficiencies are 98.4 , 62.3 and $99.4 \%$ respectively.

\section{Conclusion and prospects}

Feasibility and interest of coupling wet air oxidation and packed-bed biofilm reactors have been demonstrated on phenol degradation. Biological treatment clearly enhances TOC removal and allows limiting wet air oxidation to phenol degradation. Moreover, PBBR is also able to slightly improve phenol degradation.

It has been demonstrated that two PBBRs in series with a phenol-acclimated PBBR followed by an acetic acid-fed PBBR is necessary to limit the phenol inhibitory effect and thus to improve performances. Optimisation of the first PBBR in terms of temperature, hydrodynamics, $\mathrm{pH}$ and aeration process seems very important to avoid residual phenol in the intermediate effluent and so to improve TOC removal efficiency in the second PBBR.

Furthermore, both processes were successfully modelled separately:

- For WAO, a continuous bubble was simulated from literature data. A simplified hydrodynamic model was assumed, so it would be interesting to further enhance this simulation by taking into account a more complex hydrodynamic behaviour.

- A PBBR model was implemented from experimental and literature data. Regarding the phenol-acclimated PBBR model, good accordance was found between modelled and experimental phenol removal efficiencies. It also
Table 4 Influence of different parameters on phenol removal efficiency

\begin{tabular}{llc}
\hline Parameter & Parameter variation & Removal efficiency variation \\
\hline Phenol flow rate & $-50 \%$ & $+15.4 \%$ \\
& $+50 \%$ & $-8.8 \%$ \\
Phenol initial concentration & $-50 \%$ & $+0.2 \%$ \\
& $+50 \%$ & $-0.4 \%$ \\
Biomass density in biofilm & $-50 \%$ & $-1.9 \%$ \\
& $+50 \%$ & $+0.7 \%$ \\
\hline
\end{tabular}


Table 5 Results of WAO and PBBR models as a coupled process

\begin{tabular}{lcll}
\hline Phenol & $\begin{array}{l}\text { Flow rate } \\
\left(\mathrm{mg} \mathrm{h}^{-1}\right)\end{array}$ & $\begin{array}{l}\text { Modelled removal } \\
\text { efficiency }\end{array}$ & $\begin{array}{l}\text { Experimental removal } \\
\text { efficiency }\end{array}$ \\
\hline $\begin{array}{l}\text { WAO influent } \\
\text { WAO effluent/PBBR }\end{array}$ & 2790 & $/$ & $/$ \\
$\quad$ influent & 109 & $96.1 \%$ & $97 \%$ \\
$\begin{array}{l}\text { PBBR effluent } \\
\text { Final removal efficiency }\end{array}$ & 47 & $57.1 \%$ & $60 \%$ \\
\hline
\end{tabular}

appeared that most of the reaction occurred in the first half part of the biofilm. This demonstrates that a fine compromise is to be found on backwashing frequency to increase both reactional volume (with less inactive biomass) and sludge retention time.

At the end, the continuous coupled process was modelled using WAO simulation effluent as influent of the PBBR model. Experimental results were well fitted by the simulation ones, and phenol flow rate influence was assessed. Other parameters as WAO operation temperature or phenol concentration would have to be assessed in the future.

A next stage would be to include potential recycling streams between biological treatment and chemical oxidation steps. This global simulation would allow optimising the coupled process design in order to improve its performances in terms of both removal efficiencies and energy consumption. The modelling and simulation parts are hence very important to further work on the economic positioning of this kind of coupling processes.

\section{References}

Assalin MR, dos Santos AE, Durán N (2009) Combined system of activated sludge and ozonation for the treatment of Kraft E1 effluent. Int J Environ Res Public Health 6:1145-1154

Bajaj M, Gallert C, Winter J (2008) Biodegradation of high phenol containing synthetic wastewater by an aerobic fixed bed reactor. Bioresour Technol 99:8376-8381

Benitez FJ, Beltran-Heredia J, Torregrosa J, Acero JL (1999) Treatment of olive mill wastewaters by ozonation, aerobic degradation and the combination of both treatments. J Chem Technol Biotechnol 74: 639-646

Busca G, Berardinelli S, Resini C, Arrighi L (2008) Technologies for the removal of phenol from fluid streams: a short review of recent developments. J Hazard Mater 160:265-288

Debellefontaine H, Crispel S, Reilhac P, Périé F, Foussard JN (1999) Wet air oxidation (WAO) for the treatment of industrial wastewater and domestic sludge. Design of bubble column reactors Chem Eng Sci 54:4953-4959

di Laconi C (2012) Biological treatment and ozone oxidation: integration or coupling? Bioresour Technol 106:63-68

Fan LS, Leyva-Ramos R, Wisecarver KD, Zehner BJ (1990) Diffusion of phenol through a biofilm grown on activated carbon particles in a draft-tube three-phase fluidized-bed bioreactor. Biotechnol Bioeng $35: 279-286$
Guieysse B, Norvill ZN (2014) Sequential chemical-biological processes for the treatment of industrial wastewaters: review of recent progresses and critical assessment. J Hazard Mater 267:142-152

Hsien TY, Lin YH (2005) Biodegradation of phenolic wastewater in a fixed biofilm reactor. Biochem Eng J 27:95-103

INERIS, (2006) Fiche de données toxicologiques et environnementales du phénol (french).

Ishak S, Malakahmad A (2013) Optimization of Fenton process for refinery wastewater biodegradability augmentation. Korean J Chem Eng 30:1083-1090

Kantarci N, Borak F, Ulgen KO (2005) Bubble column reactors. Process Biochem 40:2263-2283

Lefèvre S, Boutin O, Ferrasse JH, Malleret L, Faucherand R, Viand A (2011a) Thermodynamic and kinetic study of phenol degradation by a non-catalytic wet air oxidation process. Chemosphere 84:12081215

Lefèvre S, Ferrasse JH, Faucherand R, Viand A, Boutin O (2012) Energetic optimization of wet air oxidation process using experimental design coupled with process simulation. Energy 41:175-183

Lefèvre S, Ferrasse JH, Boutin O, Sergent M, Faucherand R, Viand A (2011b) Process optimisation using the combination of simulation and experimental design approach: application to wet air oxidation. Chem Eng Res and Des 89:1045-1055

Lei Y, Shen Z, Huang R, Wang W (2007) Treatment of landfill leachate by combined aged-refuse bioreactor and electro-oxidation. Water Res 41:2417-2426

Libra JA, Sosath F (2003) Combination of biological and chemical processes for the treatment of textile wastewater containing reactive dyes. J Chem Technol Biotechnol 78:1149-1156

Logan BE (2012) Environmental transport processes, Wiley.

Mantzavinos D, Psillakis E (2004) Enhancement of biodegradability of industrial wastewaters by chemical oxidation pre-treatment. J Chem Technol Biotechnol 79:431-454

Mantzavinos D, Kalogerakis N (2005) Treatment of olive mill effluents: part I. Organic matter degradation by chemical and biological processes - an overview. Environ Int 31:289-295

Marrot B, Barrios-Martinez A, Moulin P, Roche N (2006) Biodegradation of high phenol concentration by activated sludge in an immersed membrane bioreactor. Biochem Eng J 30:174-183

Minh PD, Gallezot P, Azabou S, Sayadi S, Besson M (2008) Catalytic wet air oxidation of olive oil mill effluents: 4 treatment and detoxification of real effluents. Appl Catal B Environ 84:749-775

Nuhoglu A, Yalcin B (2005) Modelling of phenol removal in a batch reactor. Process Biochem 40:1233-1239

Oller I, Malato S, Sánchez-Pérez JA (2011) Combination of advanced oxidation processes and biological treatments for wastewater decontamination - a review. Sci Total Environ 409:4141-4166

Pawlowsky U, Howell JA (1973) Mixed culture biooxidation of phenol. I. Determination of kinetic parameters. Biotechnol Bioeng 15:889 896

Pariente MI, Siles JA, Molina R, Botas JA, Melero JA, Martinez F (2013) Treatment of an agrochemical wastewater by integration of heterogeneous catalytic wet hydrogen peroxide oxidation and rotating biological contactors. Chem Eng J 226:409-415 
Pishgar R (2011) Anaerobic biodegradation of phenol: comparative study of free and immobilized growth. Iran J Energy Environ.

Ranade VV, Chaudhari R, Gunjal PR (2011) Trickle bed reactors: reactor engineering \& applications. Elsevier, Netherlands

Rivas J, Gimeno O, Portela JR, de la Ossa EM, Beltrán FJ (2001) Supercritical water oxidation of olive oil mill wastewater. Ind Eng Chem Res 40:3670-3674

Saravanan P, Pakshirajan K, Saha P (2008) Growth kinetics of an indigenous mixed microbial consortium during phenol degradation in a batch reactor. Bioresour Technol 99:205-209

Scott JP, Ollis DF (1995) Integration of chemical and biological oxidation processes for water treatment: review and recommendations. Environ Prog 14:88-103

Van Swaaij WPM, Charpentier JC, Villermaux J (1969) Residence time distribution in the liquid phase of trickle flow in packed columns. Chem Eng Sci 24:1083-1095
Verenich S, Kallas J (2002) Wet oxidation lumped kinetic model for wastewater organic burden biodegradability prediction. Environ Sci Technol 36:3335-3339

Wang X, Han J, Chen Z, Jian L, Gu X, Lin CJ (2012) Combined processes of two-stage Fenton-biological anaerobic filter-biological aerated filter for advanced treatment of landfill leachate. Waste Manag 32:2401-2405

Warnock JN, Bratch K, Al-Rubeai M (2005) Packed bed bioreactors. In: Chaudhuri J, Al-Rubeai M (eds) Bioreact. Tissue Eng. Springer, Netherlands

Zapata A, Malato S, Sánchez-Pérez JA, Oller I, Maldonado MI (2010) Scale-up strategy for a combined solar photo-Fenton/biological system for remediation of pesticide-contaminated water. Catal Today 151:100-106

Zeng M, Soric A, Roche N (2013) Calibration of hydrodynamic behavior and biokinetics for TOC removal modeling in biofilm reactors under different hydraulic conditions. Bioresour Technol 144:202-209 